\title{
The idea of community and its practice: Tensions, disruptions and hope in Glasgow's urban growing projects
}

The Sociological Review 202I, Vol. 69(2) 484-499 (C) The Author(s) 2021

(c) (1)

Article reuse guidelines: sagepub.com/journals-permissions DOI: 10.1 I $77 / 0038026 \mid 20982272$ journals.sagepub.com/home/sor

(S) SAGE

\section{Helen Traill}

University of Glasgow, UK

\begin{abstract}
The question of what community comes to mean has taken on increasing significance in sociological debates and beyond, as an increasingly politicised term and the focus of new theorisations. In this context, it is increasingly necessary to ask what is meant when community is invoked. Building on recent work that positions community as a practice and an ever-present facet of human sociality, this article argues that it is necessary to consider the powerful work that community as an idea does in shaping everyday communal practices, through designating collective space and creating behavioural expectations. To do so, the article draws on participant observation and interviews from a community gardening site in Glasgow that was part of a broader research project investigating the everyday life of communality within growing spaces. This demonstrates the successes but also the difficulties of carving out communal space, and the work done by community organisations to enact it. The article draws on contemporary community theory, but also on ideas from Davina Cooper about the role of ideation in social life. It argues for a conceptual approach to communality that does not situate it as a social form or seek it in everyday practice, but instead considers the vacillation between the ideation and practices of community: illustrated here in a designated community place. In so doing, this approach calls into focus the frictions and boundaries produced in that process, and questions the limits of organisational inclusivity.
\end{abstract}

\section{Keywords}

communing, community gardens, ethnography, everyday sociality, Glasgow

\section{Introduction}

The question of what community comes to mean has taken on an increasing significance in sociological debate and beyond. With the heightened political focus on local communities as a locus for self-determination, political power and revitalisation, it is critical to

\section{Corresponding author:}

Helen Traill, University of Glasgow, Adam Smith Business School, Main Building, University Avenue,

Glasgow, GI2 8QQ, UK.

Email: Helen.traill@glasgow.ac.uk 
interrogate what comes to be called community and how. The term remains enticing and evocative, if increasingly plastic. Despite the strong temptation to simply eject it from our analytical vocabulary, I argue there are good reasons to instead focus on its slippery evocations and practices to get a clearer sense of contemporary communality. To that end, the aim of this article is to discuss community as an active idea shaping collective practices; in Brubaker's (2013) terms, recognising it as a 'category of practice'. This is to take seriously the ideational power of the term.

Recent theorisations have moved from an understanding of what community is, to seeing it as a form of sociality and action (Blokland, 2017; Studdert \& Walkderine, 2016a, 2016b). Building on this insight, this article's contribution is to demonstrate the power and limits of community as an idea within communal projects in relation to that sociality. In order to do so, I explore the space between the ideation and the practices of community through drawing on an ethnography of community gardening in Glasgow. Consequently, this article also extends the community gardening literature's limited engagement with community as a concept.

Considering community is particularly prescient given the myriad of political meanings the term can take on. Firstly, there is the work the idea has done in the context of centrally-imposed austerity (Amin, 2005; Wallace, 2010). Community can work as a language for responsibilisation (Amin, 2005), centring localised, usually third-sector, support for the needs of individuals often as funding for such support is cut. The danger thus lies in supporting the 'roll-back' aspects of neoliberalisation, through providing the safety net previously embodied in the now-hollowed-out welfare state. This is Peck and Tickell's (2002, p. 390) " "little platoons" in the shape of (local) voluntary and faith-based associations in the service of neoliberal goals'. Community can thus be a moral language to justify making people responsible for each other. Paradoxically, this occurs as funding for community places and projects is cut and the spaces themselves are deemed 'substitutable' (Robinson \& Sheldon, 2018).

Nonetheless, such political co-optation does not erase the hope and collectivism also central to the language of community. The expression of solidarity that underpins the neoliberal critique is also a source of optimism, praised for example in community gardening as a positive phenomenon in and of itself (e.g. Quayle, n.d.; Tan \& Neo, 2009). Community can be imbued with a variety of political hopes: for example, as a vessel for social change, or as an agent in local planning and participatory budgeting (Ganuza \& Baiocchi, 2012; Lawson \& Kearns, 2010, 2014; Williams et al., 2014). In this approach emerges a possible 'progressive localism', which Featherstone et al. (2012, p. 179) see in 'strategies that . . . create positive affinities between places and social groups negotiating global processes'. This is a vision of outward-looking, non-parochial local connection. In this highly politicised context, how community is approached as an analytical construct is important, not least because community is both a loaded term and the anchor around which these debates recur.

What I propose is an analytical approach that takes seriously existing communal practices in contemporary life, but does not lose sight of those symbols and politics that community carries as an idea, however slippery, circular or contradictory they may be. This draws on the work of Cooper (2013) to see the everyday life of community in 'oscillation' between idea and practice. I pursue this double vision as a way of foregrounding the 
contestation at the heart of urban communality, and the work of producing that which comes to be called community. This recognises the continued importance of community as a social idea, however multifaceted and ideological (Cohen, 1985; Mulligan, 2015).

\section{Working with/in community}

Recent reimaginations of the concept of community have foregrounded sociality and action, principally in the work of Studdert and Walkderine (2016a, 2016b) and Blokland (2017). Instead of seeing community as a social object, they position it as an activity already central to social life. Elements of understanding community as a practice are not new, with the pivotal account of Cohen (1985) highlighting community as a symbolic construction and collective gloss, rather than a social form. Yet community has offered something of a conceptual headache, and as Blokland (2017, p. 6) argued, as a concept it is 'out of fashion, even old-fashioned' in academic work. While community had not disappeared from sociological discourse, it had often been subject to questions around its contemporary salience particularly as to whether it referred to something contemporaneously missing, especially in the urban (Bauman, 2001). In reformulating communality as 'a sociality of interdependent necessity' (Neal et al., 2019, p. 72), as more practice-oriented formulations of community do, the communality of everyday life can be foregrounded without cleaving to community as a fixed form.

This article extends this approach through interrogating this everyday sociality with reference to the conceptual life of community, as a lay term. This is to recognise the interrelation of idea and practice within community projects. In so doing, it demonstrates the centrality of that sociality so importantly recognised in practice-oriented approaches to community, while making the case for attention to be paid to the plasticity of the idea so often evoked in relation to it. This is critical as it directly informs not only who comes to be involved in community processes, through boundary practices, but also what activities go unrecognised (cf. Wills, 2016).

It is necessary in what follows then to maintain a careful analytical distinction between the idea of community (and its unavoidable uses in the field) and the communal practices (or communing) that constitute the daily life of an urban growing project. Studdert and Walkerdine (2016a, 2016b) utilise the language of 'communing' and 'being-ness' to discuss the everyday sociality of collective life. They note that community is 'an elastic word serving multiple agendas' (Studdert \& Walkerdine, 2016b, p. 3). But the danger of moving away from that language to centre communing is that it pushes aside the question of how different agendas and ideas are articulated ambivalently through the word itself.

Community as a term has an inescapable empirical pull as a symbolic category and political signifier (Brint, 2001; Mulligan, 2015). It is undoubtedly however a dubious category of analysis. Its fulfilment, in Jean-Luc Nancy's (1991) philosophical sense, amounts to the total loss of the individual, leading him to argue that it is 'inoperable' as a concept. Yet community clearly remains a meaningful idea in everyday circulation (Brubaker, 2013). There is a need then to remain attentive to the power of community as an idea to frame and promote social action, without slipping into positioning it as a social object or a useful analytical construct. When some encompassing term is required to refer to the movement between the community as an idea and communal practices, the 
idea of communality is a useful overarching term that lacks some of the heavier baggage of community. As this article explores, the gnarled language of community can obfuscate as well as open up communal practices.

\section{Thinking with the community in community gardening}

This approach extends work on communality but it also engages with a specific communal growing literature that, despite burgeoning in recent years, is yet to take seriously communing as a practice. The literature on community gardening deals very well with issues from the politics of land use (Eizenberg, 2012) to the production of neoliberal governmentality (Pudup, 2008). But there is limited engagement with the relationship between communality and growing, beyond noting that one facilitates some form of the other. Work by Neo and Chua (2017) takes this further by suggesting growing and community as ideals within the practice often pull in opposite directions.

Mostly however the literature is limited by a narrow engagement with community conceptually. It is often taken as an a priori thing, such as in Witheridge and Morris (2016, p. 202) where they utilise a definition from Greenspace Scotland (2011): 'Community gardens are locally managed pieces of land that are developed in response to and reflect the needs of the communities in which they are based.' Not only circular, this takes as a given the existence of putative communities in which and upon whose needs the gardens are based. What is missing in this approach is a critical questioning of the centrality of community as an active idea. Pudup (2008), in recognition of its baggage, reframes the subject of her research as 'organised garden projects'. But by bracketing off community, this approach elides the social life and the politics of the term.

Instead of taking community as a static thing, or a concept with too much baggage, it is important to unpack the different meanings of community within growing as a practice. Kurtz's (2001) work usefully notes the enclosure inherent in urban gardening and ties this back to the bounded social dynamics that she finds present in gardens in Minneapolis (cf. boundary work within community sociology, e.g. Belton, 2013; Cohen, 1985). Kurtz's work is important in noting how the invocation of community can create unmet expectations around sociality in gardens that are often more akin to individual allotments than truly shared growing endeavours. In this article, I want to build on Kurtz's insights to focus on the dynamics around the invocation of community and extend it through an engagement with the recent sociological work on communality discussed above.

After introducing the case study and methodology, this article draws on material from the field to engage directly with the social life of community as both idea and practice. The article details the boundaries and equivocations brought up by community as a term through the ethnographic material, as well as the stubborn hopefulness within the communal practices found within community gardening. In this way, I explore the ambiguities of how community is imagined and practised within an urban community project.

\section{Researching Woodlands Community Garden}

Since a community garden is nominatively a space for doing something that might be called community, it is an ideal phenomenon through which to explore what relation 
this nominative identity has to collective practices. The site this article draws its material from is the Woodlands Community Garden, a growing project established in 2010 and run by the Woodlands Community Development Trust (WCDT). Unusually, WCDT has owned the land of the community garden since the 1980s, having been gifted it by the council for housing development that was never carried out. Today, WCDT is a charity that is, in the words of the manager, 'community led, and that's where our priorities remain'. It runs the garden, but also a weekly community meal and a recently constructed community meeting space, as well as outreach activities and community clean ups. This article is focused on the community garden as its longest established project and one that members of the public often deal with as a discrete communal place, though in practice there is a flow of volunteers and users between the different projects of the Trust.

The Woodlands Community Garden site consists primarily of raised beds, around 40 in 2015-16. The raised beds are leased out on an individual or family basis to so-called 'raised bedders' for an annual fee (reduced for the unwaged). Described by one grower as a 'community within a community' (a practice which already suggests some nuance to the enactment of community as idea), the raised bedders often have a strong attachment to the project, becoming invested monetarily and emotionally in the garden. During my fieldwork, I became a raised bedder. I volunteered many hours of my labour alongside participants during twice-weekly gardening sessions where non-raised bedders also come along to volunteer and tend to the wider garden, which includes a number of fruit bushes and trees, and some communal beds. The site is also always open for casual use because of an organisational commitment to inclusion.

The Woodlands Community Garden as a case study informed a broader research project investigating communal growing and its relations to urban land use, communality and inclusion. I carried out a multi-sited urban ethnography that stretched iteratively across two growing seasons, between April and October in 2015 and 2016. This involved 200 hours of participant observation and 34 interviews with participants and organisers of two established growing sites, often held on-site as 'go-along' interviews (Kusenbach, 2003 ) to ground them in the everyday life of the projects.

While the participants are all anonymised, I took the decision not to anonymise the projects within the research. This follows precedent, as many studies in the community gardening field do not anonymise their projects. But more robustly, it also allows for a broader, open conversation about the Woodlands area, and allows a collaboration with WCDT for example in academic presentations. Within this ongoing relationship and in conversations with WCDT, it was agreed that the risk of harm to the garden or its gardeners as a result of this naming was low.

This article draws material only from the Woodlands Community Garden, rather than both case studies of the research, in order to give a richer illustration of a community growing site within the bounds of the article than would be possible in comparison. The community garden offers an evocative illustration of a space that is declaratively communal and yet home to contradiction and tension around what that means. In utilising such a case study, this article speaks to the work that goes into trying to articulate community spaces within the tensions created by the idea of community itself. 


\section{Growing and communing}

The Woodlands Community Garden is a place where community-as-idea is regularly evoked, formally by the organisation but also in everyday talk. One obvious and institutional way the symbolism of community recurs is in the naming of places and projects. By way of example, a volunteer training programme was known as 'Growing a Community' and involved participants in a four-session course that taught them basic growing skills, including composting, tools and maintenance, and covered too issues such as biodiversity and mental health. One of the main benefits cited by participants (who were often volunteers or raised bedders in the garden) was a chance for them to get to know each other better. The naming practices of WCDT frame its social space in a specific way, without necessarily defining what or whom community means. Nevertheless, in doing so, they open the garden up as a space for participants to get to know each other. These practices form part of the organisational work WCDT does to bring people together, in many ways to curate communality via the idea of community.

To explore whether and how community comes to be recognised in communal practices entails considering what Cooper (2013) calls the conceptual lines of ideas. She writes about how in the pursuit of everyday utopias one can see an 'oscillation' (Cooper, 2013 , p. 37) between imagination and actualisation. This is to see everyday practice as dynamic, and suggests that attempting to live an ideal informs what is then imagined. Cooper's consideration of the conceptual lines involved in trying to bring ideals to life is suggestive of an important connection between lay imaginings and everyday social life. In invoking the idea of community, projects evoke belonging, villages, safety, connectivity and many other emotional and practical resonances. Yet the process of actualising this, of bringing it to life, is not smooth. While some of what occurs in the garden reflects expectations evoked by the idea of community, for many it feels uncomfortable to align the garden with an idea it only partially resembles (cf. Kurtz, 2001).

Nevertheless, the nominative practices of WCDT are part of the important work that goes into facilitating connection through labelling spaces as communal. It sets up expectations around the existence of collective behaviour (cf. Kurtz, 2001). Repeated weekly, communal feeling builds between prior strangers (cf. Studdert \& Walkerdine, 2016b). As one newer raised bedder, Samantha, noted in an interview, 'the second time I went, the same people were there, and they'd remembered my name, and there was just something so nice about that'. At its most basic, this is the curation of practices of knowing.

Further, as Samantha's experience as a new gardener attests, there is an important element of openness and inclusion central to the imagination of community at Woodlands - it is importantly open to a putative 'everyone'. This is articulated in mundane material ways around for example refusals to padlock the site to keep out those who would use the space to drink or smoke in the evenings, and sometimes leave refuse and damage in their wake. It also underpins institutional efforts to understand, via a local survey done with a consultant, how they relate to the wider neighbourhood, and where there might still be work to be done. Yet, as work by Blokland (2008) has demonstrated, social differences of race and class can impact on the capacity of projects to build social connection between participants - particularly due to different understandings of reciprocity and the benefit of engagement. Thus, a laudable 
ideological commitment to inclusion can sit awkwardly against implicit cultural values embedded within communal practices, as will be explored below.

\section{Care and non-committal friendship}

Nevertheless, there are plenty of practices that contribute to communing at the Woodlands Community Garden. A full description and analysis of those practices is beyond the scope of this article, but communing can be understood to exist in practices that create a culture of being known within the garden. Described aptly by Samantha as 'non-committal friendships', this level of non-intensive intimacy echoes Blokland's (2017) exposition of the different degrees of intensity in urban community practices, from personal intimacy to passing strangers. It also recalls sociological work such as the idea of 'friendly distance' between neighbours highlighted by Crow et al. (2002) and Morgan's (2009) work on acquaintanceship. Where this article extends such accounts is in its direct consideration of the interrelation of such non-committal friendships with the idea of community in the everyday imaginary of the garden.

Indeed, the Woodlands Community Garden offered a place where participants could come to know each other, and sometimes go for a drink together. Regular volunteers and raised bedders Adam, Mark and Lizzie all live within walking distance of the garden. All white and British, neither Adam nor Lizzie were in steady employment, and Mark was only occasionally employed by the garden itself. As a result, all three were free to attend Wednesday afternoon growing sessions. Through growing together at the garden as raised bedders and volunteers, a casual companionship emerged. After a trip to visit another project and get some inspiration (and seaweed), Lizzie and Adam were off to the pub. They called across the garden to Mark, 'You coming?' Mark calls back over that he has a friend visiting and can't this time. It has become a rhythm for them, frequenting the same local pub around the corner from the garden together after garden activities. In these everyday ways, Woodlands becomes a place for building social connections locally and beyond, though they often remained at an immediate level: based in the here and now of growing alongside one another or passing an hour at the pub.

Yet Woodlands was also home to demonstrations of care. To give a brief example, consider the care taken over Adam. Adam was a regular volunteer at Woodlands during the fieldwork. He was adept at putting together structures from scrap wood and he helped build raised beds and a potting bench. When he was volunteering, a great deal of care was taken to make sure that Adam did not overstretch himself as he was recovering from a serious accident. Although relatively mobile, he had been out of work for quite a few years. After staying one evening until $6 \mathrm{pm}$ to finish off the potting bench, he was notably stiff the next day during the growing session. The garden worker made a point of checking on him, and asked that he let her know if anything he had previously offered to do turned out to be too much. Because Adam is well known in the space of the garden, he is taken care of and welcome to do as much or as little as he can manage. He is also trusted to know his limits. This echoes the work of Crossan et al. (2015) when they situate Glasgow's community gardens as 'communities of care', which is to say spaces in which attention is paid to growers and volunteers' various needs. Thus, communality and care in the Woodlands Community Garden are closely intertwined. 


\section{Equivocation}

Nonetheless, community as an idea does not always sit easily alongside these collective practices. For many who are involved in the growing project there was equivocation over whether it was sensible to call Woodlands a community. I interviewed Samantha sitting outside a cafe along from the garden while she was pregnant with her first child. We'd started volunteering at Woodlands at a similar time, but Samantha had gone on to work for the Trust, helping with research and designing flyers. She was close to the project and talked at length about how much good it had brought her, in various ways. But the language of community was a stumbling block. At first, when asked what community meant to her, she acknowledged difficulty expressing this, saying:

I find it really difficult to articulate myself sometimes. I feel like I've found a community.

But Samantha seemed less than happy to commit to this, particularly uneasy about the lack of families at the garden. As the conversation continued, a contrast with another project illuminated what was missing for Samantha:

But I feel like what I see going on at [the other project] is more community ... Having children's groups, events that seem different to the garden ... I know, obviously, [WCDT] want to do stuff like that but yeah I like what I see coming from [the other project] for families.

\section{Later adding:}

[Woodlands is] Kind of a group of waifs and strays to be honest!! I've not met any local business owners apart from the woman from the breathing place, the lovely breathing centre. I've not met anyone from local businesses coming in. I've not met any neighbours who come in for a chat. It's like, obviously there are people who go there who are neighbours of the garden, but they are volunteers of the garden. You never see anyone popping in saying, oh hi guys nice to see what you're up to, oh that tree's grown, or you know I've never been there and that's happened.

Samantha shows discomfort with the idea of community, coming at the idea through a contrast with another Glasgow project that she sees as more community-oriented because of the greater involvement of families and those immediately adjacent to the space. Instead, she sees Woodlands as home to 'waifs and strays' that are in some sense dislocated from the geographical neighbourhood. In this, it is worth noting that she and I are both white middle-class women in an area with a sizeable ethnic minority population, who also constitute a number of the local shop owners. Census results from 2011 show a significant number of people in the Woodlands neighbourhood categorise themselves as Scottish Asian or Asian (23\% versus the Glasgow average of 8\%; National Records of Scotland, 2014). The other community project she mentions is nearby, yet in an area with a much smaller minority ethnic population.

Samantha reflected on her place within this disjuncture, having carried out a local survey for WCDT, and felt that the Asian shopkeepers were largely disinterested in the garden or the broader Trust. She noted that, 'doing the surveys, people of certain 
ethnicities in this area ... in some of the Asian supermarkets and things, they're not really that interested'. So while she initially noted she had 'found a community', she then unpicks this, going on to say, 'But then, what I have at the garden isn't really a community then', based on this disconnect from the local area.

Despite having a strong emotional attachment to the garden and its users, Samantha's equivocal account of whether this amounts to community highlights that a personal connection to a specific place can be troubled by a holistic vision of what community might mean. Samantha's doubling back could be interpreted as a respondent being inarticulate about a complex social idea (Payne \& Grew, 2005). Yet Samantha is not inarticulate, but instead holds a variety of views on what constitutes and feels like community at once. I had known Samantha for over a year by the time we had the interview, so we could wade through the ideas together (with sympathy for Sinha \& Back's [2014] idea of 'sociable' methods). In conversations with Samantha, the tensions and ambiguity around community-as-idea in this context become clear.

Samantha's equivocal account is emblematic of the everyday slipperiness of the term, as well as questions of race, class and neighbourhood boundary, all of which are pertinent to whether the term 'community' sits easily at a project or not. Woodlands' naming of itself as both a community in itself and after the neighbourhood is part of this trouble. In this, it stakes a double claim: to connection and to place. The difference between those involved at the garden and the social make-up of the neighbourhood, as well as embedded cultural expectations around what idealised community ought to look like, thus creates frictions around the fit of community-as-idea at Woodlands.

\section{Dissonance}

Communing thus also happens against and outwith community-as-idea. In practice, growing together in a community garden and sharing its space were not always seen as sufficient to be termed community. Often, this dissonance was an expression of boundaries similar to those present in Samantha's account. This is echoed through Chloe's feeling that she and her family are not part of any putative community. I saw Chloe regularly at Woodlands, sometimes with one or other of her children, sometimes during formal gardening sessions, but often not. She had a rather prominent raised bed, right in the centre of the garden. She described feeling social pressure to maintain it, but uncertainty about what she was a part of at the Woodlands Community Garden:

I ask if she feels like part of anything down here, and she says 'I don't feel like we're part of the community, we've not really been down enough. I feel like we're part of a community project though, if that makes sense.' (Extract from field notes)

What Chloe was wading through is the difficulty of connecting her activity at the Woodlands Community Garden, communal as it sometimes is, with the idealised notion of 'a community'. She felt there was only a weak resemblance to that idealised construct, particularly for those who have not spent enough time there, as she feels she has not. Notably, as Chloe pointed out to me, she and her family live nearby the garden, but in an area known as Park. The symbolic boundary between the two neighbourhoods enhances the difficulty Chloe has in ascribing the community idea to what is done at Woodlands. 
The distinction between Park and Woodlands as neighbourhoods is found in differences of wealth, class and ethnicity. As noted, Woodlands has a substantial ethnic minority population by Glaswegian standards. Indeed, a mosque sits next door to what was the office of WCDT in 2016. Yet participants in the garden are by and large white. Chloe's discomfort in claiming a part in any nominatively Woodlands community, as a white woman who lives beyond an imagined neighbourhood boundary, can be made sense of in relation to these geographies of belonging that problematise a strictly metonymic relationship between the garden's naming and the neighbourhood's diversity of residents. Notably too, Park has some of the most expensive property in Glasgow; whereas Woodlands is comparatively cheaper and has a great deal of housing in multiple occupation and a high rate of turnover, according to research carried out by WCDT. Chloe's evocation of the neighbourhood boundary foregrounds a broader, more complicated story about who comes to belong.

Here it is worth briefly returning to the illicit uses of the garden, usually associated with local youths smoking marijuana on the roof of a small building in the garden, known as the hub, to the complaint of next-door neighbours. While this poses an issue for the garden in terms of occasional damage and littering (and one which they struggle to directly confront besides the use of anti-climb paint as a deterrent), ideationally this is a rejectionist practice. Instead of joining the everyday social life of the project, illicit uses offer a reimagination of the space outside of the community projected there and one which separates itself from the communing of the garden temporally, often taking place in the evenings. It suggests an alternative claim on the space outwith the communality of the growing project, and subtly questions its claim to neighbourhood representation. Given the role of WCDT in local politics, particularly engaged in greening the street the community garden sits on and planning to build artist studios in gap sites, it matters who embraces and who rejects this vision of community. That illicit users (known to the gardeners only as 'local youths') and the local Asian population are disengaged suggests the implicit boundaries of this communing.

\section{Who belongs?}

Some of the difficulty around community as a lay concept comes from the nominative declaration of the Woodlands garden. Claiming to be of or for (or 'run by') a geographically delimited community can produce a jarring effect if the constituents of the project differ from the neighbourhood named. Given the local ethnic minority population, it is notable that the community garden is predominantly occupied by white people (even if they are European and white). The proximity of a local mosque to the community garden might seem to lend itself to working in partnership, but there is little connection. Instead, there are hints of local friction. Howard, a younger, some-time volunteer who grew up nearby, spoke of rumours of a disagreement over a gap site WCDT had recently taken over. In describing it, he was not sure if it represented a 'race thing' or a 'class thing':

In Woodlands is there not a bit of a, slight race thing. Not a race thing, but a class divide between the garden which is mostly white people, not only, but then there the - I heard there was a conflict with that space next door? Someone wanted to turn that into, the mosque 
wanted to, the Imam from the mosque wanted that turned into a car park for the mosque apparently ... so it's like there is some community there and it's contrasting with the white community.

Howard moves between class and ethnicity, suggestively eliding 'a race thing' and 'a class divide'. He is trying to establish that there is a gap - moving through the ideas of race, class and coming back to the 'white community'. He struggles to decide whether class or race is the appropriate frame for this social distinction: the blurring of the two is suggestive of the intersection of these signifiers. Nonetheless, as Howard and others point out, there is a gap between the Woodlands garden participants and another putative community based around the mosque, although the idea of both of these as communities perhaps situates a greater deal of cohesion here than actually exists. What this narrative emphasises are the cultural boundaries of the garden as a 'white community'. This highlights the slippage and ambiguity of the lay concept of community. It moves in various accounts between signifying ethnicity, activity and place, and becomes disrupted in this movement. Perhaps what is affirmed in this is that community is an always-partisan enactment, always somewhat tribal (Anderson, 2006; Belton, 2013; Cohen, 1985); and that urban neighbourhood boundaries are deeply contested and deeply felt (Fraser, 2013; Madden, 2014). This has clear implications for how community might be accepted in relation to naming and these boundaries; and the tensions of inclusion and exclusion always implicit in communal formations.

\section{Community as a hopeful horizon}

Nevertheless, despite sitting uncomfortably for some, community often remains a term of hope. Even within discourses that deny the applicability of community, the possibility of entering into connection and overcoming some of these boundaries can be found. For example, while Chloe feels detached from some putative Woodlands community, she feels like she is part of something that is communal and that she could join, if she wanted. Community in this context is a language of hope. It is a gesture towards a possible future, despite rubbing uncomfortably against attempts to practise it (Cooper's (2013) 'oscillation' in everyday utopias). Delanty (2003, p. 130) talks of contemporary communities as 'wilfully constructed', and this will to connect is in part expressed in postponing community to some unknown point in the future. It is evident in the wilful work often done by community organisations to curate communal spaces, despite tensions between communal practices and community-as-idea.

This is apparent in accounts such as that offered by Daniel and his family. Daniel and his wife were involved in the early days of the site but moved away for a few years. They had only just returned to Glasgow when they took up a raised bed towards the end of the research project. Daniel had helped to build the garden, though his wife was not as involved in the early years because she was pregnant and then caring for their eldest child. Thus, Daniel has a historical connection to the site, but when asked about community, and whether Woodlands constituted one for Daniel and his family, he was uncertain. Primarily, Daniel expressed uncertainty as to whether Woodlands was a community 
for them yet. This did not mean he questioned Woodlands as a place for everyday sociality, saying 'it's good to have a place where people know you, where you can have a place to be known' (Field notes, May 2016). But crucially for them, it was still 'early days', despite having been involved in the literally early days of the site.

Daniel's account suggests that having a historical connection to the site is not in itself enough to guarantee a feeling of connection in the present. Daniel knows only a few of the gardeners, because of raised-bed turnover. Gardeners come and go, refreshing with a new intake each February, as beds are reallocated from those who no longer use or want theirs. This is about time - Daniel and his family had only been back in Glasgow, and back in the garden, for a few months. Community-as-idea here again is disrupted by the fluidity and temporality of everyday life, particularly in Daniel's case by his mobile geography. But rather than rejected out of hand, community is retained as a hopeful possible horizon. Spending 'enough time' at Woodlands Community Garden is seen as a necessary threshold to joining the putative community there, to build up a connection to it. In this sense, there is a notable inner circle of those who are close to the project, roughly co-terminous with the raised bedders who, as one long-standing volunteer and raised bedder put it, constitute the 'community within a community'.

The shared commitment enshrined in this inner circle speaks to a longer-term temporality. This temporality of community as a lay idea bears echoes of kinship ties and generations of connection, which is troubled in Woodlands as it is yet to exist for a generation and has an annual churn of volunteers and raised bedders. There is within the garden a suggestive attraction to the idea of 'garden babies', as if their claim to generational time might be established in the birth of children into the collective endeavour. Samantha's first child and that of another raised bedder, Eloise, are claimed as garden babies, and cooed at and passed round accordingly. Yet Daniel's eldest daughter is the original garden baby, so even this generational claim can be disrupted. The crux however of longnurtured ties is symbolised in this attention paid to children. The future-orientation of this echoes too through practices of care described earlier, in support for rehabilitation and the continued health of gardeners.

What recognising the postponement of community-as-idea opens up is the notion that community is not just resonating or not, it is also a utopian horizon. This hopeful attitude sometimes comes to fruition: when first named, the garden was a gap site and a small collection of volunteers. That it is now defended by long-time gardeners as 'not just a garden, it's a community!' shows how this hopeful futurity can have a concrete effect. In this light, the idealism of community-as-idea demonstrates a temporal hope regarding communality's boundary processes, pushing the possibility of connection into a future where thresholds of obligation and difference have been crossed.

Yet given the tensions around inclusion and communality, particularly highlighted in the present absences within Woodlands, some boundaries might be more easily transgressed than others. The sense that the garden is a 'white community', despite casual and sometimes illicit uses by those who would not fit this label, speaks to a cultural boundary that is present within the way community is enacted. While the Trust is aware of this, and attempts to mitigate it through materialising 'openness' and attempting to be welcoming, this does suggest the limitations of an institutional vision of inclusion as simply being 'open'. 


\section{Conceptualising communality}

What the empirical material illustrates then is the value of considering the impact of community as an idea within community projects. This builds on insights from recent theorisations of community as sociality, extending them in emphasising the importance of considering the ideational. This highlights some of the necessary considerations when employing an approach to community as an everyday practice. In Blokland's (2017) useful work on community practices as part and parcel of the fabric of city life, she critiques approaches to community that see it as static or inherently connected to place. Whilst this is a limitation of predefining a social object designated by the term community, exploring the role of community ideation at Woodlands Community Garden exposes how the lay concept can function with a strong geographical sense. It also highlights how other ideas - inclusion, cultural boundaries, ethnicity and time - are also entangled in what is imagined as community.

In staying alive to the ideational aspects of urban community - its evocations and its utopian moments - it is possible to understand better the work that goes into connecting people within community projects, and perhaps its institutional limits. This is to remember, as Blokland notes, that community is also about a shared sentiment that holds together a variety of meanings and practices (Cohen, 1985). Her previous work demonstrated where this has failed to work (Blokland, 2008), when shared meanings fail to emerge between those of different social classes and projects suffer. An ideationally nuanced approach can recognise the deliberate work that community projects put in to pursuing a collective gloss, and also its institutional limits.

Within this work the possibility for a reframing emerges. The Woodlands Community Development Trust situates explicitly what it does and what is built between people involved in its projects as community. In this, it opens up the question of whether community as a lay concept might be able to mean something beyond the archetypal notion of the pure village or island community, something not holistic and unitary, but fluid, open and always in progress. Whether indeed engaging with such communal projects could change lay conceptions of communality is an open question that remains unanswered within the scope of this research.

\section{Conclusion}

The experience from the Woodlands Community Garden suggests that community as an idea reinforces, curates and creates dissonances within communal practices. This suggests that a focus on the relation of communing to community-as-idea is a fruitful way of untangling the complexities of urban collective life. As Neal et al. (2019, p. 72) argue, focusing away from the term community 'sublimates rather than replaces community's relevance to contemporary social relations'. Contemporary accounts that refocus on community do so to rejuvenate communal practices as an ever-present facet of urban life, rather than lost in some now mist-shrouded past (Blokland, 2017; Studdert \& Walkerdine, 2016a, 2016b). This helpfully recognises practices of communality that might otherwise be deemed a poor fit with the idea of community (Day, 2006; Wills, 2016). Building from this, I have argued that analytically separating out the idea of 
community and communal practices allows a degree of sensitivity to the ways that community is always in a process of being built and renewed (Delanty, 2003; Mulligan, 2015) as well as contested in the everyday. What emerged at the Woodlands Community Garden was community as evoked and argued over, wrangled with and set upon a pedestal. Seeing community as an imperfectly enacted idea highlights these contestations at the heart of staking a claim to communal life, and the contradictions emerging between communality and inclusion.

Seeing community as both verb and idea revitalises the question of how a 'sociality of interdependent necessity' is pursued (Neal et al., 2019, p. 72); of what gets recognised as communal and what goes unseen. It also could lead to a more flexible approach to understanding the variegated needs of different places and times, in terms of bringing people together and doing regenerative work, without forcing people into fixed ideas about what community should look like or do (Day, 2006; Wills, 2016). What bringing in the resonance of community-as-idea highlights are the latent politics and boundaries around what comes to be called community that are unavoidably present in everyday life. This approach could therefore be useful in examining the kinds of visions and enactments that emerge within community consultation and indeed community empowerment, and the boundaries within those processes.

Theoretically, this means recognising the practices of communing in relation to the 'collective gloss' of community as an idea (Cohen, 1985). Following Cooper (2013), this is to map the strong connection between ideation and practice in everyday life. This article demonstrates the murky and contradictory pulls of the community idea; particularly, its elasticity. It is also suggestive of how community as an idea might be open to change through time and how it might take on new meanings in relation to communal enactments. This horizon is important given contemporary concerns around the work that community-as-idea is made to do, within neoliberal responsibilisation or as a vessel for social rejuvenation. It is critical then to stay with the frictions and potentials within communality, and recognise some of community-as-idea's limits.

\section{Funding}

This work was supported by an Economic and Social Research Council doctoral studentship [grant number 1510541].

\section{References}

Amin, A. (2005). Local community on trial. Economy and Society, 34(4), 612-633. http://doi. org/10.1080/03085140500277211

Anderson, B. (2006). Imagined communities (2nd ed.). Verso.

Bauman, Z. (2001). Community: Seeking safety in an insecure world. Polity Press.

Belton, B. (2013). 'Weak power': Community and identity. Ethnic and Racial Studies, 36(2), 282-297. http://doi.org/10.1080/01419870.2012.676198

Blokland, T. (2008). Gardening with a little help of your (middle class) friends: Bridging social capital across race and class in a mixed neighbourhood. In T. V. Blokland \& M. Savage (Eds.), Networked urbanism: Social capital in the city (pp. 147-171). Ashgate.

Blokland, T. (2017). Community as urban practice. Polity Press. 
Brint, S. (2001). Gemeinschaft revisited. Sociological Theory, 19(1), 1-23. http://doi.org/ 10.1111/0735-2751.00125

Brubaker, R. (2013). Categories of analysis and categories of practice: A note on the study of Muslims in European countries of immigration. Ethnic and Racial Studies, 36(1), 1-8. http:// doi.org/10.1080/01419870.2012.729674

Cohen, A. (1985). The symbolic construction of community. Routledge.

Cooper, D. (2013). Everyday utopias: On the conceptual life of promising spaces. Duke University Press.

Crossan, J., Shaw, D., Cumbers, A., \& McMaster, R. (2015). Report: Glasgow's community gardens: Sustainable communities of care. University of Glasgow.

Crow, G., Allen, G., \& Summers, M. (2002). Neither busybodies nor nobodies: Managing proximity and distance in neighbourly relations. Sociology, 36(1), 127-145. https://doi. org $/ 10.1177 / 0038038502036001007$

Day, G. (2006). Community and everyday life. Routledge.

Delanty, G. (2003). Community. Routledge.

Eizenberg, E. (2012). Actually existing commons: Three moments of space of community gardens in New York City. Antipode, 44(3), 764-782.

Featherstone, D., Ince, A., Mackinnon, D., Strauss, K., \& Cumbers, A. (2012). Progressive localism and the construction of political alternatives. Transactions of the Institute of British Geographers, 37(2), 177-182. http://doi.org/10.1111/j.1475-5661.2011.00493.x

Fraser, A. (2013). Street habitus: Gangs, territorialism and social change in Glasgow. Journal of Youth Studies, 16(8), 970-985. http://doi.org/10.1080/13676261.2013.793791

Ganuza, E., \& Baiocchi, G. (2012). The power of ambiguity: How participatory budgeting travels the globe. Journal of Public Deliberation, 8(2), 1-12.

Greenspace Scotland. (2011). Community growing in Scotland.

Kurtz, H. (2001). Differentiating multiple meanings of garden and community. Urban Geography, 22(7), 656-670. http://doi.org/10.2747/0272-3638.22.7.656

Kusenbach, M. (2003). Street phenomenology. Ethnography, 4(3), 455-485. http://doi. org/10.1177/146613810343007

Lawson, L., \& Kearns, A. (2010). Community engagement in regeneration: Are we getting the point? Journal of Housing and the Built Environment, 25(1), 19-36. http://doi.org/10.1007/ s10901-009-9168-7

Lawson, L., \& Kearns, A. (2014). Rethinking the purpose of community empowerment in neighbourhood regeneration: The need for policy clarity. Local Economy, 29(1-2), 65-81. http:// doi.org/10.1177/0269094213519307

Madden, D. J. (2014). Neighborhood as spatial project: Making the urban order on the downtown Brooklyn waterfront. International Journal of Urban and Regional Research, 38(2), 471-497. http://doi.org/10.1111/1468-2427.12068

Morgan, D. (2009). Acquaintances: Space between intimates and strangers. Open University Press.

Mulligan, M. (2015). On ambivalence and hope in the restless search for community: How to work with the idea of community in the global age. Sociology, 49(2), 340-355. http://doi. org/10.1177/0038038514534008

Nancy, J.-L. (1991). The inoperative community. University of Minnesota Press.

National Records of Scotland. (2014). 2011 Census data. www.scotlandscensus.gov.uk/

Neal, S., Bennett, K., Cochrane, A., \& Mohan, G. (2019). Community and conviviality? Informal social life in multicultural places. Sociology, 53(1), 69-86. http://doi.org/10.1177/ 0038038518763518 
Neo, H., \& Chua, C. Y. (2017). Beyond inclusion and exclusion: Community gardens as spaces of responsibility. Annals of the American Association of Geographers, 107(3), 666-681. https:// doi.org/10.1080/24694452.2016.1261687

Payne, G., \& Grew, C. (2005). Unpacking 'class ambivalence': Some conceptual and methodological issues in accessing class cultures. Sociology, 39(5), 893-910. https://doi. org/10.1177/0038038505058371

Peck, J., \& Tickell, A. (2002). Neoliberalizing space. Antipode, 34(3), 380-404. http://doi. org/10.1111/1467-8330.00247

Pudup, M. B. (2008). It takes a garden: Cultivating citizen-subjects in organized garden projects. Geoforum, 39(3), 1228-1240. http://doi.org/10.1016/j.geoforum.2007.06.012

Quayle, H. (n.d.). The true value of community farms and gardens: Social, environmental, health and economic. Federation of City Farms and Community Gardens.

Robinson, K., \& Sheldon, R. (2018). Witnessing loss in the everyday: Community buildings in austerity Britain. The Sociological Review, 67(1), 111-125. http://doi.org/10.1177/ 0038026118797828

Sinha, S., \& Back, L. (2014). Making methods sociable: Dialogue, ethics and authorship in qualitative research. Qualitative Research, 14(4), 473-487. https://doi.org/10.1177/1468794113490717

Studdert, D., \& Walkerdine, V. (2016a). Being in community: Re-visioning sociology. The Sociological Review, 64(4), 613-621. http://doi.org/10.1111/1467-954X.12429

Studdert, D., \& Walkerdine, V. (2016b). Rethinking community research: Inter-relationality, communal being and commonality. Palgrave Macmillan.

Tan, L. H. H., \& Neo, H. (2009). 'Community in bloom': Local participation of community gardens in urban Singapore. Local Environment: The International Journal of Justice and Sustainability, 14(6), 529-539. http://doi.org/10.1080/13549830902904060

Wallace, A. (2010). New neighbourhoods, new citizens? Challenging 'community' as a framework for social and moral regeneration under New Labour in the UK. International Journal of Urban and Regional Research, 34(4), 805-819. http://doi.org/10.1111/j.1468-2427.2009.00918.x

Williams, A., Goodwin, M., \& Cloke, P. (2014). Neoliberalism, Big Society, and progressive localism. Environment and Planning A, 46(12), 2798-2815. http://doi.org/10.1068/a130119p

Wills, J. (2016). (Re)locating community in relationships: Questions for public policy. The Sociological Review, 64(4), 639-656. http://doi.org/10.1111/1467-954X.12431

Witheridge, J., \& Morris, N. J. (2016). An analysis of the effect of public policy on community garden organisations in Edinburgh. Local Environment, 21(2), 202-218. http://doi.org/10.10 80/13549839.2014.936843 
